\title{
UTILIZING A NEW TECHNOLOGY OF ENGLISH DISCOVERIES PLATFORM IN IMPLEMENTATION OF BLENDED LEARNING TO IMPROVE ENGLISH SPEAKING PERFORMANCE
}

\author{
${ }^{\# 1}$ Waode Hamsia, ${ }^{* 2}$ Yatim Riyanto, ${ }^{* 3}$ Fajar Arianto \\ ${ }^{\# 1}$ Doctoral Program Student, Department of Education of Technology, \\ State University of Surabaya, Indonesia \\ ${ }^{*}$ Lecturer, Department of Education of Technology, \\ State University of Surabaya, Indonesia \\ ${ }^{*}$ Lecturer, Department of Management of Education, \\ State University of Surabaya, Indonesia
}

Corresponding Author Email: hamsiawaode@yahoo.com

\section{A B S T R A C T}

This research focused on the implementation of blended learning through the platform of English Discoveries to analyze the relationship between blended learning to take an effort to improve self-regulated learning and learning outcomes in speaking skill. This research used a qualitative approach. The subjects were 20 students of the second semester in speaking class at Muhammadiyah University of Surabaya. The result showed that the implementation of blended learning model can improve self-regulated learning and learning outcomes in speaking skill. Therefore the blended model can be implemented successfully.

\begin{tabular}{l}
\hline \multicolumn{1}{c}{ A R T I C L E I N F O } \\
\hline Article History: \\
Received: October \\
Revised: November \\
Published: December \\
Keywords: \\
Blended Learning, \\
English Speaking \\
Performance, \\
Self Regulated Learning, \\
A New Technology of English \\
\&lish Speaking Performance. Jo- \\
Seni Prodi Pendidikan Bahasa
\end{tabular}

How to cite: Hamsia, W., Riyanto, Y., \& Arianto, F. (2020). Utilizing A New Technology of English Discoveries Platform in Implementation of Blended Learning to Improve English Speaking Performance. JoELT (Journal of English Language Teaching) Fakultas Pendidikan Bahasa \& Seni Prodi Pendidikan Bahasa Inggris IKIP, 7(2), 68-73. doi:https://doi.org/10.33394/jo-elt.v7i2.3191

\section{INTRODUCTION}

In this modern digital era, online learning is certainly needed that can be done anywhere and anytime by students. Blended learning model is the way that makes the learning activity easy because it combines a variety of ways in a process of learning and teaching. The combinations are face to face teaching and online teaching, but more than that as an element of social interaction. The students not only get a learning experience when accompanied by a lecturer in class or outside the classroom but also get a wider and independent learning experience. Therefore the learning objectives can be achieved that is the important one in the teaching process.

Educational technology is a social science that develops based on needs. These needs can arise through various problems in the learning process. To solve these problems Educational technology has its area, one of which is the area of educational technology development. By developing learning resources aimed at overcoming the problem of learning difficulties. (Seel, Barbara, and Richey, 1994: 1) argue that educational technology is a theory and practice in the design, development, utilization, management, and assessment of processes and resources for learning. This definition can emphasize that the use of learning resources has a close relationship with educational technology. While in the latest definition in AECT that Educational Technology is the study and practice ethics in an effort to facilitate 
learning and improve performance by creating, using, and managing appropriate technological processes and resources (Januszewki, A, \& Molenda, 2008).

The blended learning model integrates information and communication technology (ICT) effectively to improve teaching experience and learning outcomes for students and lecturers better. Technological advances provide opportunities for the lecturer to design and deliver lecturing to enhance the learning experience by motivating students through interactivity and collaboration. Therefore the blended learning model not only uses technology that is already available but the lecturer as a facilitator must be able to find better ways to support students achieving learning goals to be able to communicate in English to be more competitive and have the opportunity to win challenges in the world of work in the industrial era 4.0. "Too often the opportunities and advantages of the use of technology in the learning process are poorly exploited" (Oliver, R., Herrington, J., \& Reeves, 2003). Ideally, blended learning experiences should be participatory, not just interactive so that the process of cognition and collaboration are both enhanced. The students learn English in thinking and working together. Therefore the good preparation and determining the right decision is very important not only for efficient use but also a quality learning experience for the students.

The lecturer who teaches the different student levels is called dealing with mixedability class. This is a challenge even for experienced lecturers. There are various abilities of students, namely learning style, intelligence, learning ability (language competence), cultural background, motivation, and self-confidence. The idea of increasing students' English speaking performance was implemented the blended learning model in English class by utilizing new technologies, namely the English Discoveries Platform. English Discoveries is an advanced English learning platform that gives the topics in integrated learning. The topics are in reading, writing, speaking, listening, vocabulary, pronunciation, and grammar. Not only the topics are in learning English but also there are some games and magazines. The students who use the platform must be tested firstly in the placement test. Since the topics that the students get can be appropriate with the student's ability. In other words, the topics in English Discoveries consist of different levels that are basic, intermediate, and advance as the student's need. The platform is from Edusoft Ltd. that is in technology-based, comprehensive English language learning solutions, serving a wide range of educational, government and corporate sectors worldwide. http://englishdiscoveries.net/the-global-standard-in-englishlanguage-learning-solutions/.

In this research that Willey (2002) said learning objects as digital entities are used in learning which also broadly means education and training. Learning objects are defined as any digital or non-digital entity that can be used, reused, and become a reference in technology-assisted learning. Since the prospective about the definition of learning objects are still diverse, we need consistency with the literature to design and create learning objects. Lujara et al (2007) stated that learning objects can be in the form of teaching materials for long periods and may be the result of new development according to the quality of e-learning content.

In addition to the support of learning objects and the composition of the learning process time, the application of the blended learning model also needs to be supported by other factors found in students. These factors include factors within students themselves such as individual intelligence, learning abilities, learning styles, motivation, and character. The successful learning activity can be achieved if all of these factors interact properly and efficiently so that they need active and scientific control. Dong and Zhou (1994) said that These factors are called Self-Regulated Learning (SRL). In this research, SRL is defined as a way that is owned by students in conducting learning activities so that learning outcomes are obtained in accordance with their abilities. According to Woltres (2003), SRL refers to student motivation and goal orientation as a measure of active participation behavior in the 
learning process. In addition, Palacious \& Gascon (2010) stated that SLR refers to the process of student activity in learning and is defined as deliberate planning and monitoring of the cognitive and affective processes involved in the successful completion of academic assignments. Therefore Orhan (2007) said that the role of SRL in the application of the blended learning model is directly related to the active and constructive processes of students in an effort to monitor, regulate, and control their learning behavior in order to obtain information during learning.

This research used as a reference for the implementation of the blended learning model that requires supporting skills for lecturers who teach English using English discoveries so that students can optimize the learning provided. Martyn (2003) said that a successfully blended learning environment consists of one initial face-to-face meeting, online assignments (weekly) accompanied by online consultations, and closes with one final exam in the form of face-to-face or exams write in class with the assistance of the supervisor. Thus, Hooper (1992) said that students have more opportunities to develop themselves and take responsibility for themselves. It improves their social competence, increases their selfconfidence (Byers, 2001), improves their skills to gather information, and achieve achievements (Kendall, 2001).

The problems that can be raised in this research is as follows that from planning and implementation ranging from lecturer to students' learning outcomes, based on interviews with the lecturer that the results of learning speaking skill is very low. Teaching using the lecture method, question-answer, and assignments, are considered not to provide much learning experience for practicing English. While in the implementation of the Placement test there are still many students who have low scores so that the level obtained is also still relatively low for the student level. Based on these learning conditions, it takes effort in order to improve Self Regulated Learning and learning outcomes speaking skill such as providing opportunities for students to study English intensively for 24 hours anywhere and anytime. Therefore they have many opportunities to practice. Especially in online learning using English Discoveries.

\section{RESEARCH METHOD}

\section{Research Design}

This research used a qualitative method. As Bogdan and Biklen (1982) said that there are five features of qualitative research: (1) it has the natural setting as the direct source of data and the researcher is the key instrument, (2) it is descriptive, (3) it is concerned with the process rather than simply with the outcomes or products, (4) it tends to analyze data inductively, and (5) meaning is its essential concern (Researchers who use this approach are interested in the ways different people make sense out of their lives). Moreover, qualitative research pays great attention to the process rather than outcomes. This research would explain about how is the implementation model of blended learning through the platform of English Discoveries to analyze the relationship between blended learning to take an effort in order to improve the self-regulated in speaking skill.

\section{Population and Sample}

The subjects of this research are 20 students of the second-semester students of English department in speaking class.

\section{Instruments}

In this research, observation and interview techniques were used in collecting the data needed for this research. The researcher recorded what people say, observed what they do, and asked them questions when it was needed. 


\section{Data Analysis}

The data of this research is student's verbal and non-verbal language used during communication in the speaking class. Therefore a conclusion could be drawn that qualitative research focused mainly on activities or situations in which a researcher becomes a key instrument to collect the data that are in the form of words and pictures that later can be analyzed inductively.

\section{RESEARCH FINDINGS AND DISCUSSION Research Findings}

Based on observations of learning activities using the blended learning model with the English Discoveries platform for 3 meetings, it appears that the learning atmosphere is more conducive where students are enthusiastic, disciplined, and motivated while participating in learning activities. When implementing learning with the blended learning model students gave very close attention to the delivery of material by lecturers both online and more towards daily conversation practice material. While the delivery of face-to-face material is more directed at the discussion of grammar, the use of vocabulary, and pronunciation. During learning, students practiced speaking directly in English with their friends and lecturers. This triggers speaking class activities that can improve speaking skills. The lecturer was a facilitator and mediator of learning. This was consistent with the application of the blended learning model that focuses on successfully organizing the English learning experience. At this stage that the students with the guidance of lecturers elaborate on the knowledge that had been obtained online and face to face in class to support the implementation of practice using Blended Learning through English Discoveries Platform (BL-EDP). The lecturer prepared the students to learn by explaining why this teaching material is important to be mastered by their competence and provides direction for the students to explore the material online using (BLEDP) or when face to face learning. This was the preparation stage of learning to discuss material about home tours which can be used for learning speaking practices to describe rooms in the house. In practical use activities (BL-EDP), the role of the lecturer is to supervise and explain when the students asked questions and experienced the difficulties in teaching and learning process. After the discussion was over, continue with the presentation. During the presentation, other students were very attentive and seemed enthusiastic and motivated by the students who were presenting. There were the students who asked questions and gave questions to students who are presenting. In this case, the lecturer facilitated the students to construct learning experiences in mastering learning competencies. The role of lecturers in learning is as a facilitator or moderator.

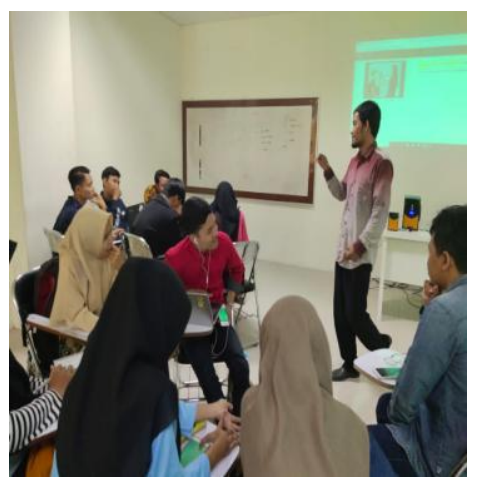

Figure 1. The Process of teaching in class

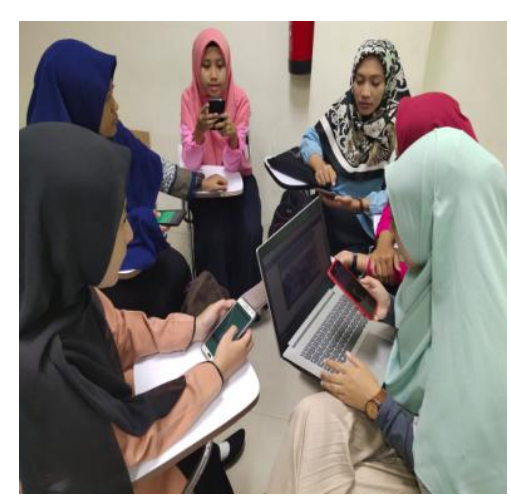

Figure 2. The process of discussing online material 


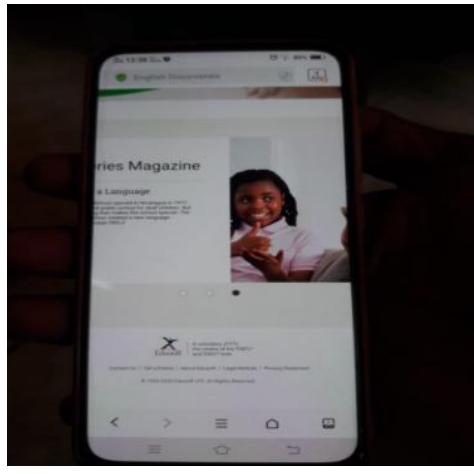

Figure 3. Accessing the material by phone

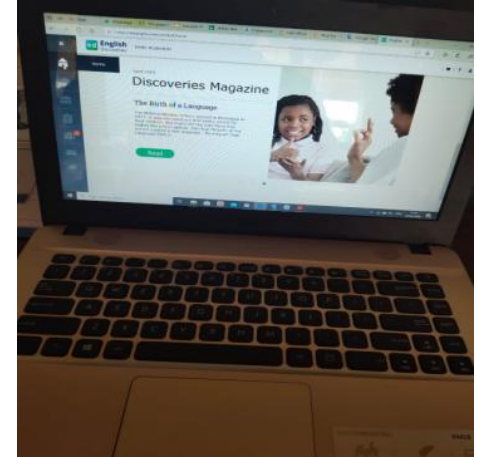

Figure 4. Accessing The material by Laptop

\section{Discussion}

The application of Blended Learning through the English Discoveries Platform and Self Regulated Learning (SRL) were directly related to the way students absorbed and got information both face to face learning and online learning. Therefore, the level of SRL supports the achievement of student academic achievement. The role and support of SRL in each student for learning done face-to-face and online using the English Discoveries platform shows the results of different speaking skills. The European Higher Education Area (EHEA) also recommends the importance of SRL for students in learning. SRL is a cognitive factor, motivation, and contextual factors that influence the learning process. SRL refers to the activeness of students in learning. SRL is as deliberate planning and monitoring of the cognitive and affective processes involved to complete tasks online. So that learning is not only controlled by external aspects but also internal aspects that are self-regulated. Therefore, learning must be understood as an active, constructive, and self-regulated process (Montalvo, F.T. \& Torres, 2004). So students who have high SRL ability have the ability to actively participate in the learning process. From the results of the SRL questionnaire given to students that they can regulate themselves, they can plan, organize, structure themselves, monitor, and evaluate themselves in learning. So motivatively, individuals who self-regulate can have self-confidence and have independence. SRL had been proven to be able to improve student speaking skills learning outcomes. The lecturer can also always monitor the progress of student learning through the Teacher Management System in the English Discoveries Platform. Therefore it can be seen that students who have a good SRL to determine the target of English learning was achieved.

\section{CONCLUSION}

Teaching and learning of speaking are an important part of any language education classroom. Not only the lecturer did the spoken language offer for learning as the main communicative skill, but it was also an important component of the learning model and learning outcomes. However, teaching speaking remained the challenging for the lecturer. This research that was implemented the blended learning model through English Discoveries platform to increase students' speaking skill and self-regulated learning. Using of the English Discoveries platform can make students easy to learn English anywhere and anytime. They can practice English for integrated skills to increase student's speaking skill. The activities are face to face and online learning that can help the students to increase their self-regulated learning of speaking skill. The students would not only learn the receptive skills that were listening and reading but also they learned the productive skills that are writing and speaking skills. The speaking skill is the most important thing in learning English language. Therefore the students can achieve the goals that how to speak English well. 


\section{ACKNOWLEDGMENT}

The authors thank to Muhammadiyah University of Surabaya for facilitating this research.

\section{REFERENCES}

Bogdan, R., \& Biklen, S. (1982). Qualitative Research for Education: An Introduction to Theory and Methods. Allyn and Bacon.

Byers, C. (2001). Interactive Assessment: An Approach to Enhance Teaching and Learning. Journal of Interactive Learning Research, 12(4), 359-374.

Dong, Q., \& Zhou, Y. (1994). Self Regulation in Students' Learning. Journal of Beijing Normal University (Social Science Edition), 1(8)-14.

Hooper, S. (1992). Cooperation Learning and Computer-Based Instruction. Educational Technology Research and Development, 40(3), 21-38.

Januszewki, A., \& Molenda, M. (2008). Education technology: A definition with commnentary. Lawrence Erlbum Association Taylor and Francis.

Kendall, M. (2001). Teaching Online to Campus, Based Students: The Experience of Using Web CT for The Community Information Module at Manchester Metropolitan University. Education for Information, 19(4), 325-346.

Lujara, S., Kissaka, M., Bhalalusesa, E., \& Trojer, L. (2007). Learning Objects: A New Paradigm for Learning Resource Development for Secondary Schools in Tanzania. International Journal of Human and Social Sciences, 3(2), 150-154.

Martyn, M. (2003). The Hibrid Online Model: Good Practice. Educause Quarterly, 1, 18-23.

Montalvo, F., \& Torres, M. (2004). Self Regulated Learning: Current and Future Direction, Spain: Department of Education: University de Navarra. Electronic Journal of Research in Educational Psychology, 2(1), 3-27.

Oliver, R., Herrington, J., \& Reeves, T. (2003). Creating Authentic Learning Environments through Blended Learning Aprroaches Global Perspectivez, Local Designs. New York: Jossey Bass. (C.Bonk \& c.graham (ed.). Jossey Bass.

Orhan, F. (2007). Applying Self Regulated Learning Strategies in a Blended Learning Instruction. World Applied Sciences Journal, 2(4), 390-398.

Palacios, A., \& Gascon, R. (2010). Self Regulated Learning in Blended Learning Environments. Attitude as Antecedent Variable. ICERI2010 Proceedings, 1678-1686.

Seel, B., \& Richey, R. (1994). Teknologi Pembelajaran Definisi dan Kawasannya. Universitas Negeri Jakarta.

Wolters, C. (2003). Understanding Procrastination from A Self-Regulated Learning Perspective. Journal of Educational Psychology, 95, 179-187. https://doi.org/10.1037/0022-0663.95.1.179. 